
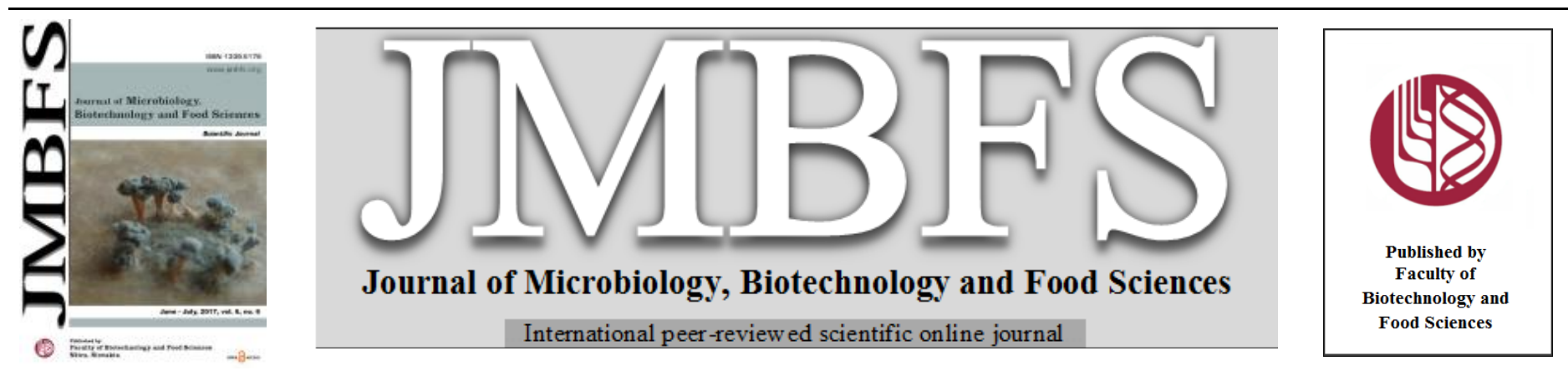

\title{
IN SILICO STUDIES ON THE EFFECT OF GRISEOFULVIN ON TUBULIN PROTEIN OF CRYPTOCOCCUS NEOFORMANS AND ITS IN VITRO VALIDATION
}

\section{Neelabh, Karuna Singh}

Address(es): Karuna Singh,

Department of Zoology, Mahila Mahavidyalaya, Banaras Hindu University, Varanasi-221005.

*Corresponding author: karunasingh5.bhu@mail.com

doi: $10.15414 /$ jmbfs.2017.6.6.1280-1283

\section{ARTICLE INFO}

Received 16. 11. 2016

Revised 28. 3. 2017

Accepted 19. 4. 2017

Published 1. 6. 2017

Regular article

open $\partial$ access

\begin{abstract}
Griseofulvin is a well known drug against dermatophytes. It is particularly prescribed for an infection called scrap ringworm or tinea capitis. In general, griseofulvin inhibits the tubulin protein that is responsible for the cell division. Not much is known about the effect of griseofulvin on Cryptococcus neoformans. Therefore, the authors made an effort to check the activity of griseofulvin against it.

The webservers (T-Coffee, Bluues simulation and CASTp) and software (Autodock 4.0) have been used in order to determine the activity of griseofulvin against the beta subunit of tubulin protein of $C$. neoformans. The results obtained from the in silico studies show a high affinity of griseofulvin towards the beta chain of tubulin protein. The negative value of binding energy $(-9.02 \mathrm{kcal} / \mathrm{mol}) \mathrm{also}$ shows that the complex is thermodynamically favourable and stable. These in silico results were further validated by MIC assay showing $74.1 \%$ inhibition of $C$. neoformans (isolate no. 5) against griseofulvin.

The present study reports that apart from dermatophytes, the drug has significant effect on $C$. neoformans and it may be used in the combinatorial therapy against the same.
\end{abstract}

Keywords: Cryptococcus neoformans; Griseofulvin; In silico; In vitro validation

\section{INTRODUCTION}

Cryptococcus neoformans is commonly known for causing cryptococcosis and cryptococcal meningitis. Most commonly the infection of C. neoformans starts with lungs but patients having advanced immune suppression end up with meningitis (Centers for disease control and Prevention, 2014). The general treatment for cryptococcosis in patients suffering from asymptomatic or mild to moderate pulmonary infections is fluconazole. This is slightly different from the treatment plan of those who have severe lung infections in which amphotericin B is prescribed in combination with flucytosine (Centers for disease control and Prevention, 2014). But in the recent past, some isolates of $C$. neoformans have shown resistance against these drugs and patients have witnessed relapse or failure on treatment with flucytosine, fluconazole and amphotericin B (LopezJodra et al., 2000).

Griseofulvin is an antifungal drug known to be produced by 3 species of Penicillium viz. P. patulum, P. griseofulvum and P. janczewskii (Drugs.com, 2015). It has been used for the treatment of human and animal dermatophytic infections. The reason for its success against dermatophytes is due to its peculiar pharmacological property that after oral administration it is localized in the keratinized cells of skin, hairs and nails. The growth of the dermatophytes parasitizing these cells is thus inhibited and removed by desquamation (Drugs.com, 2015). Many sensitivity studies have been done on the activity of griseofulvin against superficial fungal infections (Millikan, 2016). But anticryptococcal activity of griseofulvin has not been reported yet.

Many studies advocate the in vitro endorsement of the in silico results, owing to the technical limitations of bioinformatics approach. For instance, Nyarady et al (2005) validated the results of in silico prediction of epitopes by a multipin ELISA. Similarly, the mechanism of serine hydroxymethyltransferase (SHMT) inhibition by pemetrexed was validated by in vitro assays and the calculated interaction energy of pemetrexed in the active site of SHMT and the corresponding predicted binding energy were found to be in good agreement with the values of $\mathrm{K}_{\mathrm{d}}$ and $\mathrm{Ki}$ obtained in Isothermal Titration Calorimetry (Daidone et al., 2011).

The general mode of action of griseofulvin is to interact with tubulin molecule in the fungal cells (Ronnest et al., 2012). Hence, in the current manuscript the activity of griseofulvin against the tubulin protein of $C$. neoformans has been tested in silico and validation of the same has been done through the minimum inhibitory concentration assay (MIC) following the Clinical and Laboratory Standards Institute (CLSI, 2008) guidelines.

\section{MATERIALS AND METHODS}

\section{Retrieval of the structure of griseofulvin and tubulin protein}

The structure of griseofulvin (Drug data bank ID: DB00400) was obtained from drug data bank (http://www.drugbank.ca/) whereas reference structure of tubulin of Sus scrofa (wild boar) was obtained from the Protein data bank (PDB) (PDB ID: 1TUB). The sequence of beta chain of tubulin of C.neoformans was obtained from National Center for Biotechnology Information (NCBI) (Accession number: XP_568244.1). Modelling was done by Phyre $^{2}$ webserver with default parameters.

Determination of the active site region of the tubulin protein and docking studies

CASTp server, an online webserver which determines the structural pockets and cavities with the help of Delaunay triangulation and the alpha complex for shape measurements was used in order to determine the active site regions on the tubulin protein. The docking studies were performed through Autodock 4.0 (http://autodock.scripps.edu/). Further, Bluues simulation software (http://protein.bio.unipd.it/bluues/) was used to analyse the structural stability of the model. It calculates the total energy of the structure on the basis of generalized Born atom radii.

\section{In vitro studies of griseofulvin against isolates of $C$. neoformans}

Drug griseofulvin under the brand name of GRISOVIN-FP was obtained from GlaxoSmithKline and amphotericin B (AMB) (brand name AMPHOTRET) was obtained from Bharat Serums and Vaccines Limited.

\section{Micro-organisms}

One reference strain (Ref 1431), two environmental isolates (NCBI accession no. KJ175192 and KJ175193) and five clinical isolates (4CI2, 49, CSF2, CNS and CNS45) of C.neoformans were used in the study. 


\section{Antimicrobial agent}

A stock solution of griseofulvin in dimethyl sulfoxide (DMSO) at a concentration of $100 \%$ was prepared (Brilhante et al., 2014). Three controls viz. negative, vehicle (DMSO) and positive (amphotericin B), were used in the current experimental plan. The concentration range of griseofulvin against which the growth of the fungi has been tested is from $2 \mu \mathrm{g} / \mathrm{ml}$ to $1.024 \mathrm{mg} / \mathrm{ml}$..

\section{Preparation of inoculum}

The inocula of $C$. neoformans were prepared from the fresh cultures maintained in Sabouraud Dextrose Agar (SDA) medium for 48 hours at $37^{\circ} \mathrm{C}$. Each fungal culture was added to $0.9 \%$ sterile saline solution, ensuring gentle scrapping of the fungal colonies with the aid of the inoculation loop to form a fungal suspension. The resulting fungal suspension was adjusted to $0.5 \mathrm{McF}$ arland scale of turbidity. This suspension was further diluted in the ratio of 1:10 with RPMI medium to obtain the final concentration of $1.0-5^{*} 10^{6} \mathrm{CFU} / \mathrm{ml}$.

\section{In vitro susceptibility testing}

The susceptibility testing of $C$. neoformans against griseofulvin was performed according to the guidelines issued by CLSI for the broth macro-dilution method M27-A3 (CLSI, 2008) with a few modifications. An incubation time span of 72 hours and $35^{\circ} \mathrm{C}$ temperature was followed in the experiment. Additionally, all the samples were tested in triplicate.

\section{Determination of MIC}

MIC of all isolates of C.neoforams was determined using broth macro-dilution method (CLSI, 2008). The optical density of all the samples was measured at $420 \mathrm{~nm}$ using spectrophotometer (ThermoScientific UV1).

\section{Statistical analysis}

The OD readings obtained at different concentrations of griseofulvin for each isolate were statistically analysed by $\mathrm{F}$ test followed by Holm Sidak test.

\section{RESULTS}

Griseofulvin is known to interact with tubulin protein which plays an importan role during the cell division. The structure of the alpha beta tubulin of $C$ neoformans was unavailable, therefore, a multiple sequence alignment was performed between the eukaryotic tubulin protein sequences having known structures with C.neoformans tubulin sequence. T-Coffee software was used to carry out the multiple sequence alignment process (Notredame et al., 2000). A very highy sequence similarity $(99 \%)$ was found between the tubulin protein of C.neoformans and Sus scrofa (Fig 1).

MSA

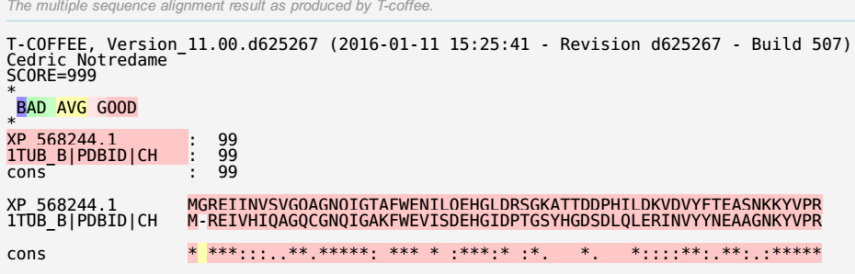

cons

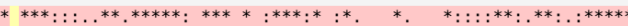

$\begin{array}{ll}\text { XP } 568244.1 & \text { STOVDLEPGVDL VRSGPLANLFRPTFVHGESGAGNNWAKGYYTEGAELVDPVIDVLROAE } \\ \text { 1TOB_B|PDBID|CH } & \text { AILVDLEPGTMDSVRSGPFGQIFRPDNFVFGQSGAGNWWAKGHYTEGAELVDSVLDVVRKESE }\end{array}$ cons $\quad: * * * * * * * .: * * * * * * . .:: * * * * . * * . *: * * * * * * * * *: * * * * * * * * * . * * * *: *::: *$

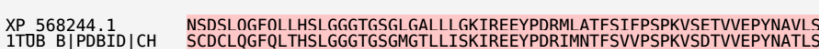
cons $\quad . .^{*} . * * * * * * * * * * * * * * * *: *: * *: .^{* * * * * * * * *}::^{* * *}: .^{* * * * * *}: * * * * * * * *, * *$

$\begin{array}{ll}\text { XP } 568244.1 & \text { THNI VENSDITCCIDNFAL YNTCVSDI KTOSPEYKDI NSI IAKVMTGFTTTIRFPGVI NSDIR } \\ 1 \text { 1TOB_B|PDBID|CH } & \text { VHQLVENTDETYCIDNEALYDICFRTLKLTTPTYGDLNHLVSATMSGVTTCLRFPGQLNADLR }\end{array}$

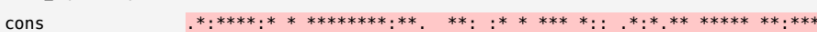

$\begin{array}{ll}\text { XP } 568244.1 & \text { KLAVMVPFPRLHFFTAGYPAPLANASKSYTASNVHELTAAIFOKRSLLAATDPLFGKYLTVS } \\ 1 \text { 1TOB B|PDBID|CH } & \text { KLAVNMVPFPRLHFFMPGFAPLTSRGSQYRALTVPELTQQMFDAKNMMAACDPRHGRYTVA }\end{array}$ cons $\quad * * * * * * * * * * * * * *, * * * * .: \ldots *: . * * . * * * * \quad: *:: .:: * * * *, *: * * * *$ :

$\begin{array}{ll}\text { XP } 568244.1 & \text { VAYRGKLISMRDIENAVWDFHNKNSEHFVPWTPNSSLITLCTVPPLGOTAAATLVANTTAISEV } \\ \text { 1TOB_B|PDBID|CH } & \text { AVFRGRMSMKEVDEQMLNVONKNSSYFVEWIPNNVKTAVCDIPPRGLKMSATFIGNSTAIQEL }\end{array}$ cons $\quad \ldots:^{* *}::^{* *}::::::::^{* * * *}::^{* *} * * * *,:^{*}:^{*}:^{* * *} .:^{* *}::^{*}::^{* *} .^{*}:$

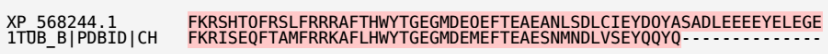
cons *** $\quad * *::^{* * *}: * * * * * * * * * * * * * * * * *: *: .^{* *} \quad * *: * *$

XP 568244.1
ITOB_B|PDBID $\mid C H \quad$ EHVEEGENYEE

cons

Figure 1 MSA of beta tubulin of S. scrofa and C. Neoformans
Henceforth, 1 TUB, the respective tubulin protein of $S$. scrofa was taken as reference in the current study. Top 10 active sites were determined on1TUB These active sites were docked with griseofulvin. It was observed that the best binding energy was obtained at pocket ID: 167 having an area of 381.6 and a volume of 590.9 (Fig 2). The docked structure of griseofulvin on this pocket has been shown in fig 3 and the docking parameters have been provided in table 1 .

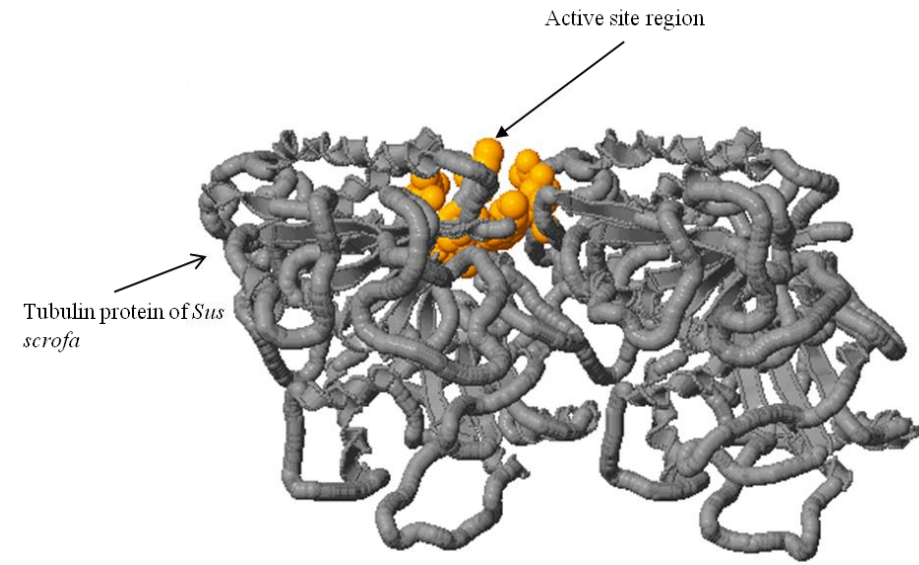

Figure 2 Prediction of active site of tubulin protein of S. scrofa

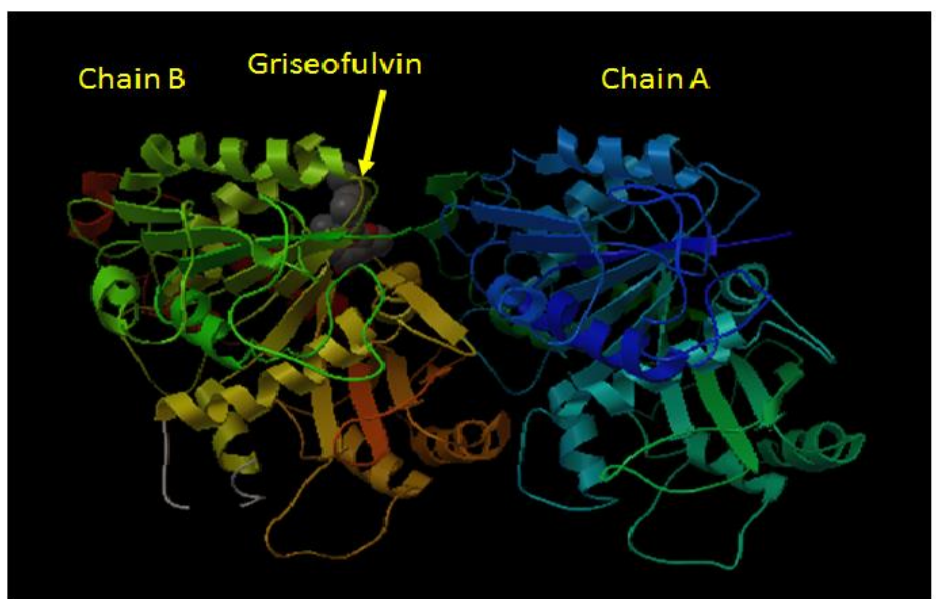

Figure 3 Best structure obtained after docking griseofulvin on tubulin protein of S. scrofa

Table 1 Parameters of the best docked structure of griseofulvin on tubulin protein (1TUB) of $S$. scrofa

\begin{tabular}{|l|l|}
\hline Parameters & Values \\
\hline Estimated Free Energy of Binding & $-9.02 \mathrm{kcal} / \mathrm{mol}$ \\
\hline Estimated Inhibition Constant (Ki) & $243.84 \mathrm{nM}($ nanomolar) \\
\hline Final Intermolecular Energy & $-9.92 \mathrm{kcal} / \mathrm{mol}$ \\
\hline vdW + Hbond + desolv Energy & $-9.84 \mathrm{kcal} / \mathrm{mol}$ \\
\hline Electrostatic Energy & $-0.08 \mathrm{kcal} / \mathrm{mol}$ \\
\hline Final Total Internal Energy & $-0.45 \mathrm{kcal} / \mathrm{mol}$ \\
\hline Torsional Free Energy & $+0.89 \mathrm{kcal} / \mathrm{mol}$ \\
\hline Unbound System's Energy & $-0.45 \mathrm{kcal} / \mathrm{mol}$ \\
\hline
\end{tabular}

Estimated Free Energy of Binding or $\Delta \mathrm{G}_{\text {bind }}$ is the most important parameter amongst various parameters shown in table 1 . It is well known that only the negative $\Delta \mathrm{G}_{\text {bind }}$ are energetically favourable. Here, the $\Delta \mathrm{G}_{\text {bind }}=-9.02$, hence this is energetically favourable and the resultant complex formed is thermodynamically stable. Docking result of the reference protein suggested that griseofulvin had a higher affinity to bind the beta chain of tubulin in comparison to its alpha chain therefore, suitable sequence of tubulin beta chain of C.neoforamans was searched for modelling it.. The modelled structure has been shown in fig 4 . 


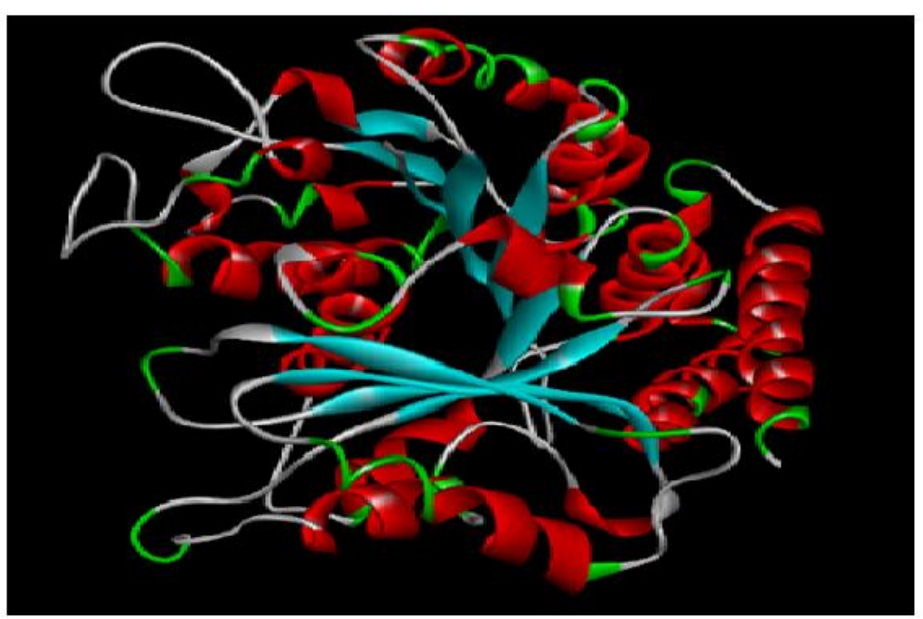

Figure 4 Modelled structure of beta tubulin of $C$. neoformans obtained by $\mathrm{Phyre}^{2}$ webserver

The obtained negative total energy assured that the model could be safely used for further docking analysis. The different parameters obtained through the Bluues software have been provided in table 2 .

Table 2 Protein stability parameters predicted by Bluues software

\begin{tabular}{|l|l|}
\hline Parameters & Values \\
\hline Born self energy: & $-16169.476521(\mathrm{~kJ})$ \\
\hline Coulomb energy: & $-109416.947909(\mathrm{~kJ})$ \\
\hline Electrostatic solvation energy: & $-4719.453945(\mathrm{~kJ} / \mathrm{mol})$ \\
\hline Total energy: & $-112139.794202(\mathrm{~kJ} / \mathrm{mol})$ \\
\hline
\end{tabular}

Again the best10 active sites for the modelled structure of beta tubulin were determined and griseofulvin was docked on all these 10 sites. It was observed that pocket ID 103 (active site region of beta tubulin of C.neoformans) having an area of 219.5 and a volume of 258.6 showed the highest binding energy when docked with griseofulvin (Fig 5 and Fig 6). The parameters related to the best docking structure obtained from Autodock 4.0 have been provided in table 3 .

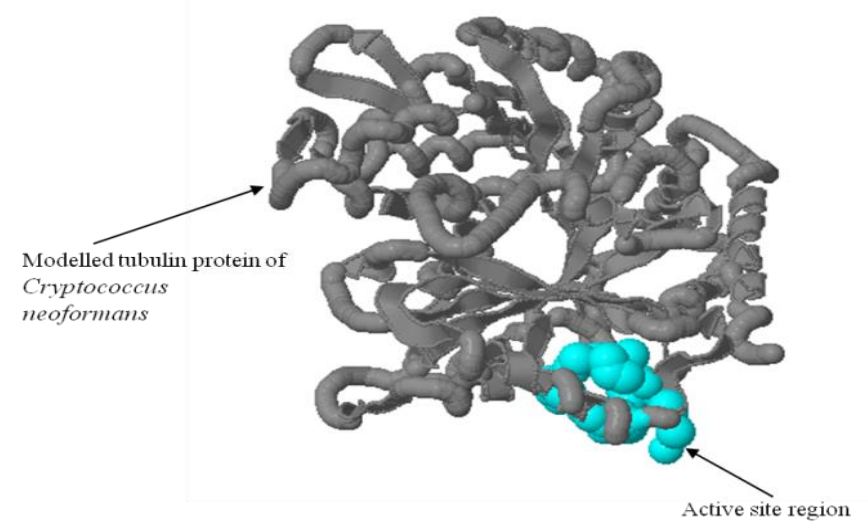

Figure 5 Prediction of active site on modelled tubulin protein of C. neoformans

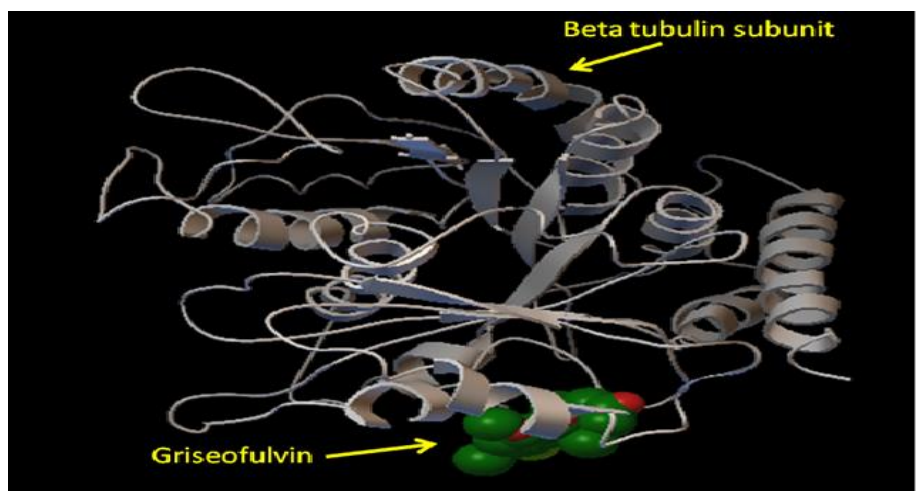

Figure 6 Best structure obtained of docking griseofulvin on beta tubulin subunit C. neoformans
Table 3 Parameters of the best docked structure

\begin{tabular}{|l|c|}
\hline Parameters & Values \\
\hline Estimated Free Energy of Binding & $-7.05 \mathrm{Kcal} / \mathrm{mol}$ \\
\hline Estimated Inhibition Constant $(\mathrm{Ki})$ & $6.75 \mathrm{uM}(\mathrm{micromolar})$ \\
\hline Final Intermolecular Energy & $-7.95 \mathrm{kcal} / \mathrm{mol}$ \\
\hline vdW + Hbond + desolv Energy & $-7.94 \mathrm{kcal} / \mathrm{mol}$ \\
\hline Electrostatic Energy & $-0.01 \mathrm{kcal} / \mathrm{mol}$ \\
\hline Final Total Internal Energy & $-0.52 \mathrm{kcal} / \mathrm{mol}$ \\
\hline Torsional Free Energy & $+0.89 \mathrm{kcal} / \mathrm{mol}$ \\
\hline Unbound System's Energy & $-0.52 \mathrm{kcal} / \mathrm{mol}$ \\
\hline
\end{tabular}

Table 3 shows that $\Delta \mathrm{G}_{\text {bind }}=-7.05$ which is energetically favourable hence providing evidence that complex formed would be structurally favourable.

Further, MIC of griseofulvin against eight isolates of C. neoformans (one reference, two environmental and five clinical) was found to inhibit the growth of the strain 4 CI2, CNS, Ref $1431,9,49$, CSF2, 5 and CNS45 by $35 \%, 43 \%, 45 \%$, $39.5 \%, 54 \%, 66.6 \%, 74.1 \%$ and $49 \%$ respectively on comparison with their respective controls (Table 4).

\begin{tabular}{|c|c|c|c|c|}
\hline Drug & Isolate & Range & MIC & $\begin{array}{l}\text { \% inhibition } \\
\text { at this MIC }\end{array}$ \\
\hline \multirow{8}{*}{ 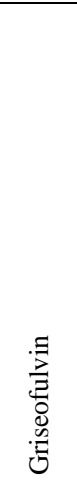 } & $\begin{array}{l}\text { C. neoformans } \\
\text { Ref } 1431\end{array}$ & $\begin{array}{c}64 \mu \mathrm{g} / \mathrm{ml}- \\
1.024 \mathrm{mg} / \mathrm{ml}\end{array}$ & $\begin{array}{c}128 \\
\mu \mathrm{g} / \mathrm{ml}\end{array}$ & $45 \%$ \\
\hline & $\begin{array}{l}\text { C. neoformans } \\
4 \mathrm{CI} 2\end{array}$ & $\begin{array}{c}64 \mu \mathrm{g} / \mathrm{ml}- \\
1.024 \mathrm{mg} / \mathrm{ml}\end{array}$ & $\begin{array}{l}1.024 \\
\mu \mathrm{g} / \mathrm{ml}\end{array}$ & $35 \%$ \\
\hline & $\begin{array}{l}\text { C. neoformans } \\
\text { CNS }\end{array}$ & $\begin{array}{c}64 \mu \mathrm{g} / \mathrm{ml}- \\
1.024 \mathrm{mg} / \mathrm{ml}\end{array}$ & $\begin{array}{c}128 \\
\mu \mathrm{g} / \mathrm{ml}\end{array}$ & $43 \%$ \\
\hline & C. neoformans 9 & $\begin{array}{c}64 \mu \mathrm{g} / \mathrm{ml}- \\
1.024 \mathrm{mg} / \mathrm{ml}\end{array}$ & $64 \mu \mathrm{g} / \mathrm{ml}$ & $39.5 \%$ \\
\hline & C. neoformans 49 & $2-64 \mu \mathrm{g} / \mathrm{ml}$ & $16 \mu \mathrm{g} / \mathrm{ml}$ & $54 \%$ \\
\hline & $\begin{array}{l}\text { C. neoformans } \\
\text { CSF2 }\end{array}$ & $\begin{array}{c}64 \mu \mathrm{g} / \mathrm{ml}- \\
1.024 \mathrm{mg} / \mathrm{ml}\end{array}$ & $\begin{array}{c}256 \\
\mu \mathrm{g} / \mathrm{ml}\end{array}$ & $66.6 \%$ \\
\hline & C. neoformans 5 & $\begin{array}{c}64 \mu \mathrm{g} / \mathrm{ml}- \\
1.024 \mathrm{mg} / \mathrm{ml}\end{array}$ & $\begin{array}{c}512 \\
\mu \mathrm{g} / \mathrm{ml}\end{array}$ & $74.1 \%$ \\
\hline & $\begin{array}{l}\text { C. neoformans } \\
\text { CNS45 }\end{array}$ & $\begin{array}{c}64 \mu \mathrm{g} / \mathrm{ml}- \\
1.024 \mathrm{mg} / \mathrm{ml}\end{array}$ & $\begin{array}{c}128 \\
\mu \mathrm{g} / \mathrm{ml}\end{array}$ & $49 \%$ \\
\hline
\end{tabular}

\section{DISCUSSION}

Griseofulvin was the only drug available for treatment of Tinea capitis, a funga infection caused by dermatophytes until the approval of terbinafine in 2007 (Gupta and Summerbell, 2000; Seebacher et al., 2007). It is known to inhibit microtubule assembly and the growth of the cells by inducing abnormal mitosis and blocking the cells at $\mathrm{G}_{2} / \mathrm{M}$ phase of cell cycle (Panda et al., 2005; Rebacz et al., 2007). Tubulin is a major structural component of microtubule and consist of $\alpha$ and $\beta$ subunits (Luduena et al., 1977). It has already been reported that griseofulvin does not disrupt the microtubules, (Watson, 2004) instead it interacts with tubulin or with one or more associated proteins of microtubules (Sloboda et al., 1982; Roobol et al., 1977; Chaudhari and Luduena, 1996).

In the present study, anticryptococcal activity of griseofulvin was performed against eight isolates of $C$. neoformans and significant $(74.1 \%)$ inhibition was observed against isolate number 5. However, MIC of griseofulvin was found to be very high than MIC of amphotericin B but low toxicity and pharmacokinetic parameters like high elimination rate of griseofulvin than amphotericin B suggests that it could be a better drug.

In the present study, due to unavailability of structure of tubulin protein of C.neoformans, structure of tubulin alpha beta dimer of S. scrofa was taken as reference. Griseofulvin was found to efficiently bind with beta domain of tubulin. Ten griseofulvin binding sites on tubulin were also predicted. Unlike, Rathinasamy et al. (2010), the binding site at Pocket ID:167 gave the best binding results. However, in case of modelled structure of beta tubulin of $C$. neoformans the best docking was obtained at Pocket ID:103.

Keeping in view, the ability of griseofulvin to inhibit mitosis in fungal cells, to stabilize microtubule dynamics and its high elimination rates, it can be suggested that the drug may be used in combination therapy for the treatment of cryptococcosis. Further, its low toxicity and weak binding to mammalian brain tubulin (Wehland, 1977; Panda et al., 2005) makes it safer for human use.

Henceforth, this study will certainly be helpful in designing more potent and specific analogues of griseofulvin against the tubulin domains of $C$. neoformans with least side effects to the host and will provide understanding about the uniqueness of binding site of griseofulvin.

\section{CONCLUSION}

Griseofulvin is a well-known drug against dermatophytes but its activity against C. neoformans is not known. The activity of griseofulvin has been tested against eight isolates of the same. In silico docking results have been validated by 
minimum inhibitory concentration assay. The high inhibition in growth gives an understanding that griseofulvin is effective against $C$. neoformans. The results obtained in this study can be extended and griseofulvin can further be investigated for its effect in in vivo condition .Its use as combinatorial therapeutic is also suggested.

Acknowledgements: One of the authors (Neelabh) gratefully acknowledges ICMR, New Delhi, India for providing the Junior Research fellowship. The authors are also thankful to The Principal, MMV, BHU for providing infrastructure facilities.

\section{REFERENCES}

Brilhante, R. S. N., Silva, N. F., de Farias Marques, F. J., Castelo, D. D. S. C. M., de Lima, R. A. C., Malaquias, A. D. M., Caetano1, E. P., Barbosa1, G. R., de Camargo, Z. P., Rodrigues, A. M., Monteiro, A. J., de Jesus Pinheiro Gomes Bandeira T., Cordeiro, R., Sidrim, J .J. C., \& Monteiro, A. J. (2015). In vitro inhibitory activity of terpenic derivatives against clinical and environmenta strains of the Sporothrix schenkii Complex. Medical mycology, 53(2), 93-98. http://mmy.oxfordjournals.org/content/53/2/93

Chaudhuri, A. R., \& Ludueña, R. F. (1996). Griseofulvin: a novel interaction with bovine brain tubulin. Biochemical pharmacology,51(7), 903-909. http://dx.doi.org/10.1016/0006-2952(95)02406-9

Daidone, F., Florio, R., Rinaldo, S., Contestabile, R., di Salvo, M. L., Cutruzzolà, F., Bossa,F., \& Paiardini, A. (2011). In silico and in vitro validation of serine hydroxymethyltransferase as a chemotherapeutic target of the antifolate drug pemetrexed. European journal of medicinal chemistry,46(5), 1616-1621. http://10.1016/j.ejmech.2011.02.009

Gupta, A. K., \& Summerbell, R. C. (2000). Tinea capitis. Medical Mycology, 38(4), 255-287. http://dx.doi.org/10.1080/mmy.38.4.255.287

López-Jodra, O., Torres-Rodriguez, J. M., Mendez-Vasquez, R., Ribas-Forcadell, E., Morera-López, Y., Baro-Tomas, T., \& Alia-Aponte, C. (2000). In vitro susceptibility of Cryptococcus neoformans isolates to five antifungal drugs using a colorimetric system and the reference microbroth method. Journal of Antimicrobial Chemotherapy, 45(5), 645-649. http://dx.doi.org/10.1093/jac/45.5.645

Ludueńa, R. F., Shooter, E. M., \& Wilson, L. (1977). Structure of the tubulin dimer. Journal of Biological Chemistry, 252(20), 7006-7014. Doi not available Millikan, L. E. (2016). Drug therapy in dermatology. CRC Press. http://dx.doi.org/10.1201/b14006

Notredame, C., Higgins, D. G., \& Heringa, J. (2000). T-Coffee: A novel method for fast and accurate multiple sequence alignment. Journal of molecular biology, 302(1), 205-217. http://dx.doi.org/10.1006/jmbi.2000.4042

Nyarady, Z., Czömpöly, T., Bősze, S., Nagy, G., Petrohai, A., Pal, J., Hudecz,F.,Berki,T., \& Nemeth, P. (2006). Validation of in silico prediction by in vitro immunoserological results of fine epitope mapping on citrate synthase specific autoantibodies. Molecular immunology, 43(7), 830-838 http://10.1016/j.molimm.2005.06.044

Panda, D., Rathinasamy, K., Santra, M. K., \& Wilson, L. (2005). Kinetic suppression of microtubule dynamic instability by griseofulvin: implications for its possible use in the treatment of cancer. Proceedings of the National Academy of Sciences of the United States of America, 102(28), 9878-9883. http://dx.doi.org/ 10.1073/pnas.0501821102

Rathinasamy, K., Jindal, B., Asthana, J., Singh, P., Balaji, P. V., \& Panda, D. (2010). Griseofulvin stabilizes microtubule dynamics, activates p53 and inhibits the proliferation of MCF-7 cells synergistically with vinblastine. BMC cancer, 10(1), 1-13. http://dx.doi.org/ 10.1186/1471-2407-10-213

Rebacz, B., Larsen, T. O., Clausen, M. H., Rønnest, M. H., Löffler, H., Ho, A. D., \& Krämer, A. (2007). Identification of griseofulvin as an inhibitor of centrosomal clustering in a phenotype-based screen. Cancer research, 67(13), 6342-6350. http://dx.doi.org/ 10.1158/0008-5472.CAN-07-0663

Rønnest, M. H., Raab, M. S., Anderhub, S., Boesen, S., Krämer, A., Larsen, T. O., \& Clausen, M. H. (2012). Disparate SAR data of griseofulvin analogues for the dermatophytes Trichophyton mentagrophytes, T. rubrum, and MDA-MB-231 cancer cells. Journal of medicinal chemistry, 55(2), 652-660. http://dx.doi.org/ $10.1021 / \mathrm{jm} 200835 \mathrm{c}$

Roobol, A., Gull, K., \& Pogson, C. I. (1977). Evidence that griseofulvin binds to a microtubule associated protein. FEBS letters, 75(1-2), 149-153. http://dx.doi.org/ 10.1016/0014-5793(77)80073-2

Seebacher, C., Abeck, D., Brasch, J., Cornely, O., Daeschlein, G., Effendy, I., Ginter-Hanselmayer, G., Haake, N., Hamm, G., Hipler, C., Hof, H. (2007). Tinea capitis: ringworm of the scalp. Mycoses, 50, 218-226. http://dx.doi.org/ 10.1111/j.1439-0507.2006.01350.x

Sloboda, R. D., Van Blaricom, G., Creasey, W. A., Rosenbaum, J. L., \& Malawista, S. E. (1982). Griseofulvin: association with tubulin and inhibition of in vitro microtubule assembly. Biochemical and biophysical research communications, 105(3), $\quad 882-888$. $\quad$ http://dx.doi.org/ 10.1016/0006291X(82)91052-X

Watson, D. H. (2004). Pesticide, veterinary and other residues in food. Woodhead Publishing. https://doi.org/10.1201/9781439823378
Wehland, J., Herzog, W., \& Weber, K. (1977). Interaction of griseofulvin with microtubules, microtubule protein and tubulin. Journal of molecular biology, 111(3), 329-342. http://dx.doi.org/ 10.1016/S0022-2836(77)80055-7

Web addresses

Centers for disease control and Prevention, 2014 http://www.cdc.gov/fungal/diseases/cryptococcosis-neoformans/definition.html Doi not available

Clinical and Laboratory Standards Institute (CLSI). 2008. Reference method for broth dilution antifungal susceptibility testing of yeasts, 3rd ed. Approved standard. CLSI M27-A3. Clinical and Laboratory Standards Institute, Wayne, PA. Doi not available

Griseofulvin, 2015 https://www.drugs.com/pro/griseofulvin.html 